społeczne debaty wokół tego powrotu i ich - jak określa autor - historyczną weryfikację. Z niekwestionowaną kompetencją, a i z dużą swobodą, wędruje ks. K. Misiaszek po tym materiale z najnowszej historii Polski. Z dociekliwością i znawstwem analizuje zmieniające się z biegiem lat, a precyzyjnie przez siebie przywoływane, regulacje prawne określające usytuowanie nauczania religii w szkole. To niezmiernie cenne fragmenty studium.

Summa summarum książka świetna, merytorycznie i formalnie dojrzała. Bardzo ważna dla debaty o tym, co się dzieje, co może i co powinno się dziać w polskiej szkole w perspektywie obecności tam nauczania religii. Lektura obowiązkowa dla każdego ambitnego, w tym zwłaszcza świadomego swych zadań katechety.

Andrzej Potocki*

\title{
Grzegorz Grzybek, Etyka rozwoju a wychowanie, Wydawnictwo Uniwersytetu Rzeszowskiego, Rzeszów 2010, ss. 160.
}

Problematyka filozofii wychowania oraz moralnych aspektów edukacji od lat stanowi przedmiot nieustających dyskusji i polemik naukowych. Oficyna wydawnicza Uniwersytetu Rzeszowskiego włączyła się także do toczącego się dyskursu, wydając książkę Grzegorza Grzybka Etyka rozwoju a wychowanie. W publikacji tej autor zmierzył się z jednym z najważniejszych problemów dotyczących przebiegu procesu wychowania, jakim jest kwestia uchwycenia prawidłowości rozwoju moralnego nie tylko wychowanka, ale także osób odpowiedzialnych za przebieg procesów tego typu. Przy takim ujęciu proces ten przestaje być jednostronnym przekazem informacji, a staje się harmonijnym współgraniem wszystkich elementów uczestniczących w jego przebiegu. Można przy tej okazji zauważyć, że autor dokonuje próby przeanalizowania problematyki wychowawczej z wykorzystaniem całego dorobku antropologii filozoficznej.

$\mathrm{Na}$ całość opracowania składa się poprzedzonych wstępem sześć rozdziałów zebranych w dwóch częściach, z których pierwsza obejmuje zagadnienia aksjologii wychowania, a druga obejmuje przedstawienie wyników przeprowadzonych badań empirycznych oraz ich analizę w kontekście usprawnienia procesów edukacyjnych. Publikację dopełnia zakończenie, postscriptum i bibliografia.

* Prof. dr hab. Andrzej Potocki OP - socjolog i teolog; pracuje w Instytucie Profilaktyki Społecznej i Resocjalizacji Uniwersytetu Warszawskiego, w Instytucie Filozofii i Socjologii Akademii Pedagogiki Specjalnej im. M. Grzegorzewskiej w Warszawie, w Kolegium Filozoficzno-Teologicznym OO. Dominikanów w Krakowie. 
Autor rozpoczyna swe wywody od wprowadzenia, w którym przedstawia cel podjętej pracy oraz prezentuje metodologiczne założenie podjętych badań empirycznych. Świadomym zabiegiem jest nadanie pierwszej części publikacji charakteru podręcznikowego, gdyż czytelnik znajdzie tam wyjaśnienia zastosowanej terminologii, podstawowe informacje na temat aksjologicznych podstaw wychowania oraz autorskiego rozumienia istoty wychowania etycznego. Każdy rozdział jest stąd poprzedzony krótkim wprowadzeniem w podejmowaną tematykę i zakończony ogólnym podsumowaniem.

W książce autor zajął stanowisko zgodne z założeniami etyki personalistycznej oraz rozwinął ujęcie wartości rozwinięte w filozofii w obrębie nurtu tomistyczno-arystotelesowskiego. Charakterystyczne jest w nim odróżnienie dobra od wartości oraz odrzucenie poglądu o ich kulturowym i czasowym zdeterminowaniu. Przy takim założeniu wartości nie zależą przyczynowo od człowieka. Inaczej mówiąc, bytowo są niezależne od niego. Założenie takie oznacza zarazem, iż człowiek z konieczności tylko je odkrywa i realizuje. Tym samym ich istnienie nie wynika wprost $\mathrm{z}$ egzystencji człowieka. Stanowisko takie pozwala jednak autorowi precyzyjnie określić ramy wychowania etycznego, jako swego rodzaju przygotowania do samodzielnego odkrywania wartości i rozbudzania motywacji do ich realizowania.

Autor wiele miejsca poświęca przedstawieniu istoty wartości konstytuujących jego koncepcję „etyki rozwoju”. Podkreślić należy, że zaproponował własną definicję wartości (w rozdz. 1.1). Oczywiście, jak każda propozycja nowego ujęcia zagadnienia, co do którego nie ma wśród samych filozofów powszechnej zgody, można z tą definicją się nie zgadzać, ale świadczy ona o konsekwentnym stanowisku i niemałej odwadze intelektualnej autora. W odróżnieniu od wielu innych publikacji w książce zaprezentowane zostały także własne definicje terminów filozoficznych, kluczowych dla wyłożenia istoty „etyki rozwoju”.

Druga część - analityczna - jest omówieniem przeprowadzonych badań empirycznych, choć nie ogranicza się tylko do ich prezentacji i zawiera szereg rozbudowanych refleksji natury teoretycznej. Prześledzenie kierunku prac, jak i poprawności przeprowadzonych analiz nieco utrudnia ograniczony zakres prezentacji zastosowanych technik badawczych, wyboru populacji respondentów oraz sposobu prezentacji wyników. Na podkreślenie zasługuje jednak fakt, iż autor przyjmuje interesujący sposób prezentacji wyników swoich dociekań, przeplatając rozważania teoretyczne wynikami uzyskanymi podczas przeprowadzonych badań.

W pracy rozwijana jest oryginalna koncepcja „etyki rozwoju”, która jak sądzić należy, będzie nadal rozwijana i doskonalona przez autora w kolejnych opracowaniach i artykułach. Koncepcja zaprezentowana w przedłożonej książce, nawet jeśli może się wydać nieco wyidealizowana, to nie umniejsza 
wartości książki, ale wskazuje na pewien trend w rozważaniach z zakresu etyki wychowania, w którym przewagę zyskują opracowania teoretyczne. Autor wprawdzie starał się takie wrażenia zatrzeć, często odwołując się do wyników badań empirycznych, ale nie zawsze wydawało się to możliwe.

Reasumując - praca Grzegorza Grzybka mieści się w moim przekonaniu w nurcie wypracowanej w Polsce tradycji ,filozofii czynu”, czyli kontynuuje najlepsze tradycje rodzimej filozofii. „Etyka rozwoju” jest bowiem nakierowana na rozbudzenie motywacji prorozwojowych u wychowanków. Do tego celu niezbędne jest jednak poprzedzające wychowanie do wartości, aby ten rozwój rzeczywiście nie tylko służył doskonaleniu się jednostki, ale także wspólnoty, którą ona reprezentuje.

Dyskurs naukowy wymaga ścierania się przeciwnych racji. W prezentowanej książce można zauważyć swego rodzaju zaproszenie do dyskusji. Jak sądzę, choćby z tego powodu dzieło to po opublikowaniu wzbudzi zainteresowanie nie tylko specjalistów, ale także wszystkich, którzy interesują się psychologią wychowania i zachowaniami człowieka w sytuacjach społecznych. Korzyść z dyskusji i polemik jest zawsze wymierna, bo jest nią poprawa istniejącego stanu rzeczy. Publikację należy zatem potraktować jako ważny głos w naukowej dyskusji o problemach współczesnej edukacji. Przesłanie publikacji jest czytelne - gdyż autor zmierza do wskazania najogólniejszych przyczyn niepowodzeń w działalności wychowawczej, jak też wskazuje na źródła takich sukcesów.

Z uwagi na nowatorski charakter przedstawionych analiz nie można przyrównywać książki do innych publikacji znanych w Polsce. Niewątpliwie zatem można byłoby rozszerzyć ilość rozdziałów, na przykład o analizy aspektów praktycznych, ale nie wydaje się, aby takie rozwiązanie mogło korzystnie wpłynąć na całość opracowania. Przyjęta przez autora struktura oraz kolejność prezentacji poszczególnych analiz wydaje się zatem trafna i pozwala na realizacje przyjętego celu badawczego. $Z$ tej racji można zasadnie mniemać, iż publikacja Grzegorza Grzybka nie tylko wzbogaca dyskurs naukowy w zakresie filozofii wychowania, ale zainteresuje wielu czytelników, którym na sercu leży dobro polskiej szkoły. Książka posiada także walor poradnika dla tych wszystkich, którzy organizują i prowadzą wychowanie w instytucjach oświatowych. Wypada więc zachęcić do lektury tej pozycji i samodzielnej analizy zawartych w niej treści, gdyż przełożenie sugestii i propozycji autora na grunt własnej instytucji oświatowej wymaga współuczestniczenia w dialogu, do którego zaprasza on czytelnika.

Stefan Konstańczak*

* Dr hab. Stefan Konstańczak, prof. UZ, profesor w Instytutcie Filozofii Uniwersytetu Zielonogórskiego. 